\title{
CONTRIBUTION OF SARCOMERIC GENE VARIANTS TO THE PREDICTION OF SUDDEN CARDIAC DEATH RISK IN FAMILIAL HYPERTROPHIC CARDIOMYOPATHY
}

\author{
AILESEL HIPERTROFIK KARDIYOMIYOPATIDE SARKOMERIK GEN VARYANTLARININ \\ ANI KARDIYAK ÖLÜM RISKININ ÖNGÖRÜLMESINE KATKISI
}

\author{
Evrim KÖMÜRCÜ BAYRAK ${ }^{1,2}$ (D) Filiz GÜÇLÜ GEYIK² (D), Gökhan KAHVECi ${ }^{3}$ (D), Fatih BAYRAK ${ }^{4}$ (D) \\ ${ }^{1}$ Istanbul University, Istanbul Faculty of Medicine, Departments of Medical Genetics, Istanbul, Turkey \\ ${ }^{2}$ Istanbul University, Aziz Sancar Institute of Experimental Medicine, Department of Genetics, Istanbul, Turkey \\ ${ }^{3}$ Kartal Kosuyolu Training and Research Hospital, Clinic of Cardiology, Istanbul, Turkey \\ ${ }^{4}$ Acibadem Mehmet Ali Aydinlar University, Department of Cardiology, Istanbul, Turkey
}

ORCID IDs of the authors: E.K.B. 0000-0003-1271-1208; F.G.G. 0000-0003-4257-9930; G.K. 0000-0001-8367-6505;

F.B. 0000-0002-1574-1085

Cite this article as: Komurcu Bayrak E, Guclu Geyik F, Kahveci G, Bayrak F. Contribution of sarcomeric gene variants to the prediction of sudden cardiac death risk in familial hypertrophic cardiomyopathy. J Ist Faculty Med 2020;83(4):345-54. doi: 10.26650/IUITFD.2020.0051

\begin{abstract}
Objective: Hypertrophic cardiomyopathy $(\mathrm{HCM})$ is one of sudden cardiac death (SCD) causes. This study aimed to identify high-risk pathogenic variants for SCD in the three sarcomeric genes with the most frequent mutations in HCM.

Material and Method: The study included 12 adult HCM index cases with a family history of SCD and/or HCM, and 31 of their family members. All the participants were evaluated with detailed cardiac examinations. The exonic regions of the MYH7, MYBPC3 and TNNT2 genes were analysed using CorTAG HCM1 resequencing arrays.

Results: Six pathogenic variants causing amino acid substitutions were found in 8 of the index cases with HCM. Five of them were identified as previously defined missense variants of Val698Ala, Arg719Trp, Met822Leu and Arg663Cys (in three cases) in the MYH7 gene, and Arg102Trp in the TNNT2 gene. For the first time in an HCM family with a history of late-onset SCD, Tyr525Asn and c. ${ }^{\star} 27-21 \mathrm{G}>$ A variants in the MYBPC3 gene were identified as compound heterozygous. These variants were not present in control subjects $(n=777)$ from the Turkish population.

Conclusion: In this study, novel variants in the MYBPC3 gene were identified in an HCM family with SCD history. However, there was no clear association between pathogenic variants and the risk of SCD.
\end{abstract}

Keywords: Sarcomeric gene variant, familial hypertrophic cardiomyopathy, sudden cardiac death

\begin{abstract}
ÖZET
Amaç: Hipertrofik kardiyomiyopati (HKM), ani kardiyak ölümün (AKÖ) nedenlerinden biridir. Bu çalışmada, HKM'de en sık mutasyon bulunan üç sarkomerik gende, AKÖ için yüksek riskli patojenik varyantların belirlenmesi amaçlandı.

Gereç ve Yöntem: Çalışmaya, AKÖ ve/veya HKM için aile öyküsü olan 12 yetişkin HKM'li indeks vaka ve 31 aile üyesi dahil edildi. Tüm katılımcılar, kardiyolojik olarak değerlendirildi. MYH7, MYBPC3 ve TNNT2 genlerinin ekzonik bölgeleri, CorTAG HCM1 dizileme sistemi kullanılarak analiz edildi.

Bulgular: HKM'li indeks vakaların 8'inde, amino asit değişimine neden olan 6 farklı patojenik varyant bulundu. Bunlardan beşinin, MYH7 genindeki Val698Ala, Arg719Trp, Met822Leu ve Arg663Cys (üç vakada) ve TNNT2 genindeki Arg102Trp değişimlerinin daha önce tanımlanmış yanlış anlamlı patojenik varyantlar olduğu belirlendi. İleri yaşta AKÖ öyküsü olan bir HKM ailesinde, MYBPC3 geninde Tyr525Asn ve c. ${ }^{\star 27-21 G>A}$ varyantlar bileşik heterozigot olarak ilk defa tanımlandı. Bu varyantlar, Türk popülasyonu kontrol örneklerinde ( $n=777)$ saptanmadı.
\end{abstract}

Sonuç: Bu çalışmada, AKÖ öyküsü olan bir HKM ailesinde yeni varyantlar tanımlandı. Ancak, HKM ailelerinde saptanan patojenik varyantlar ile AKÖ riski arasında net bir ilişki bulunamadı.

Anahtar Kelimeler: Sarkomerik gen varyantı, ailesel hipertrofik kardiyomiyopati, ani kardiyak ölüm

Corresponding author/iletişim kurulacak yazar: ebayrak@istanbul.edu.tr

Submitted/Başvuru: 06.05.2020 • Revision Requested/Revizyon Talebi: 27.05.2020 •

Last Revision Received/Son Revizyon: 27.05.2020 • Accepted/Kabul: 01.06.2020 • Published Online/Online Yayın: 30.09 .2020

(C)Telif Hakkı $2020 \mathrm{~J}$ Ist Faculty Med - Makale metnine jmed.istanbul.edu.tr web sayfasından ulaşılabilir.

(C) Copyright 2020 by J Ist Faculty Med - Available online at jmed.istanbul.edu.tr 


\section{INTRODUCTION}

Hypertrophic cardiomyopathy $(\mathrm{HCM})$ is a cardiac disease characterized by left ventricular hypertrophy, causing sudden cardiac death (SCD) or progressive heart failure (1-3). HCM exhibits familial aggregation usually with an autosomal dominant inheritance, occurring in about 1 in 500 individuals (1). The first gene localization of familial $\mathrm{HCM}$ was mapped to the locus of $\mathrm{B-MyHC}$ on chromosome 14q12 in a large French-Canadian family in 1989 (4). From this date, more than 1400 variants in the sarcomeric and non-sarcomeric genes in HCM have been identified using various techniques (5-9).

Although, in recent times, more than 40 genes have been identified in $\mathrm{HCM}$ patients by new genetic sequencing (NGS) $(8,10), \mathrm{HCM}$ is mostly due to pathogenic single nucleotide variants (SNVs) (53-85\%) in the MYH7 gene encoding cardiac ß-myosin heavy chain ( $\mathrm{B}-\mathrm{MyHC}$ ), the MYBPC3 gene encoding cardiac myosin binding protein-C (cMyBP-C) and the TNNT2 gene encoding cardiac troponin $\mathrm{T}(\mathrm{c} T \mathrm{nT})(2,3,11)$.

In this study, our aim was to identify novel high-risk pathogenic variants in the MYH7, MYBPC3 and TNNT2 genes in Turkish HCM families with SCD history, and also to perform retrospective clinical evaluations of variant carriers.

\section{MATERIAL AND METHOD}

\section{The participants of study}

The study included 12 index HCM cases (8 male/4 female; age range at diagnosis 16-67 years) with a family history of HCM and/or SCD, and their 31 family members. Study subjects were evaluated with a clinical history, physical examination, electrocardiography and echocardiography. This study was conducted in accordance with the ethics standards of the Ethics Committee of the University of Istanbul, Istanbul Faculty of Medicine and with the Helsinki Declaration (1964), and informed consent was obtained from the study subjects.

\section{Variant detection}

The genomic DNA samples were extracted from peripheral leukocytes. The coding regions and flanking intronic sequences of the MYH7, MYBPC3 and TNNT2 genes were screened in 12 index cases using array-based resequencing (CorTAG HCM1 Mutation Detection Assay based on Affymetrix CustomSeq Resequencing Arrays). This assay comprised primer sets for the long-range amplification of all coding regions and intron flanks. Pools of fragmented PCR-products were then hybridized and analysed with high-density oligonucleotide probe arrays. All novel variants and previously reported pathogenic variants were confirmed with Sanger sequencing after touchdown polymerase chain reaction (PCR) and control of the amplicons by $2 \%$ agarose gel electrophoresis.
Primer sequences are shown in Table 1. The individual and possible pathogenic variants were researched in index cases and family members using the RFLP-PCR method or direct Sanger sequencing. The usage restriction enzymes in the RFLP-PCR method for genotyping of variants were listed in Table 2 . The selection of the variant specific restriction enzyme and the lengths of the fragments were determined using the software RestrictionMapper (http://www.restrictionmapper.org.)

\section{Database analysis}

dbSNP, ClinVar, VarSome, American College of Medical Genetics and Genomics-ACMG Standards (12) for interpretation classification of variants, and HGMD Professional (Human Genome Mutation Database; BIOBASE) were used to describe the variants in the sarcomeric genes. The variants detected in our HCM patients were also screened in 777 distinct individuals from the in-house exome database of the Advanced Genomics and Bioinformatics Research Center (IGBAM) as a control group.

\section{In silico analysis}

The pathogenicity and conservation scores of variants were checked in VarSome using in silico tools such as MutationTaster, DANN, SIFT, PROVEAN and GERP. Moreover, Alamut (Interactive Biosoftware, trial version 2.6, Rouen, France) was used to predict whether the novel intronic variants change the characteristics of the splice signals and exonic splicing enhancers (ESE) binding sites on genes. ESEs predictive tools were used to identify the ESEs site for serine/arginine proteins such as SF2/ ASF, SC35, SRp40, and SRp55. And also, in this software, the splice site variants were analysed using five prediction tools (SpliceSiteFinder-like, NNSPLICE, GeneSplicer, Human Splicing Finder and MaxEntScan). Default thresholds were used for all the analyses.

\section{RESULTS}

In this study, disease-causing variants of the MYH7, MYBPC3 and TNNT2 genes in $12 \mathrm{HCM}$ families were searched, and pathogenic variants were identified in eight of them (Figure 1). Twelve index cases had a left ventricular maximal wall thickness $>15 \mathrm{~mm}$, and had a family history of SCD and/or HCM. In the genetic analysis of three sarcomeric genes of the index cases, a total of fifteen single nucleotide variations (SNV) were detected. Only six (five already defined and one novel) of these SNVs were pathogenic variants causing amino acid substitutions. Two novel uncertain significance intronic variants as well as seven non-pathogenic variants were also detected (Table 1). Minimal allele frequencies, gene localizations, primer sequences, restriction enzyme type for RFLP-PCR analysis of these variants are demonstrated in Table 1. The minimum allele frequencies of all SNVs in the Turkish population were checked in 777 controls of the in-house exome data- 


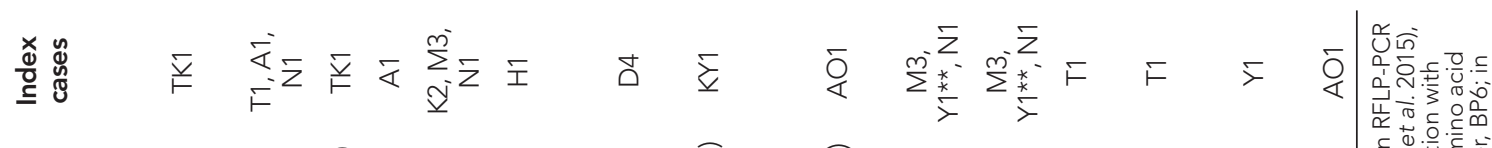

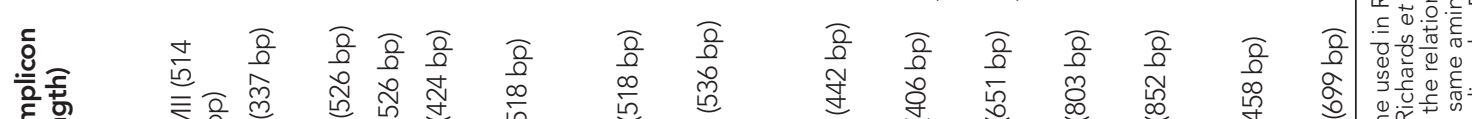

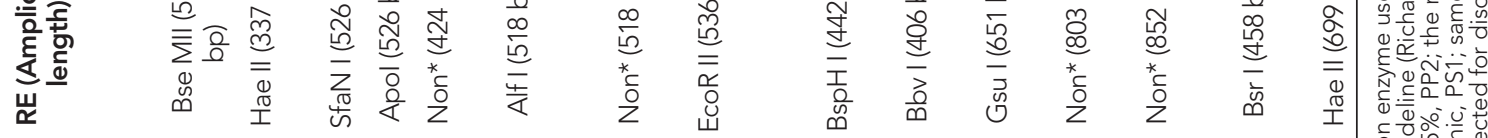
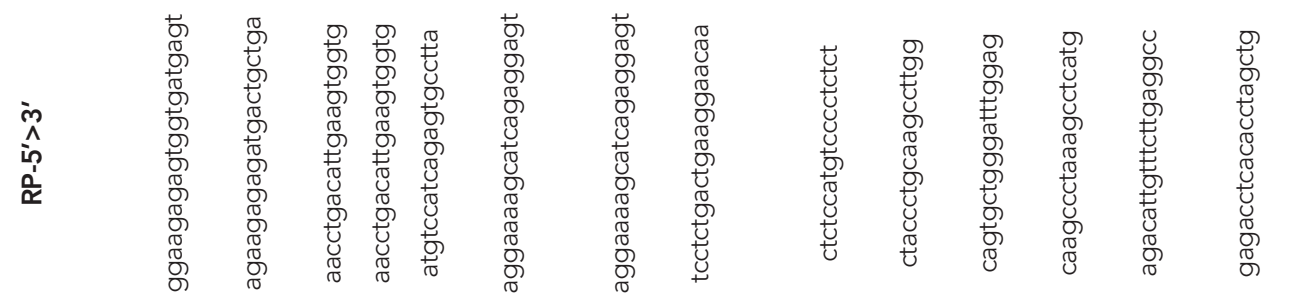

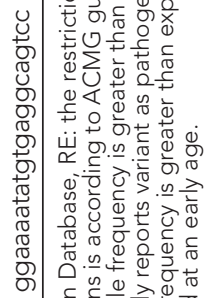
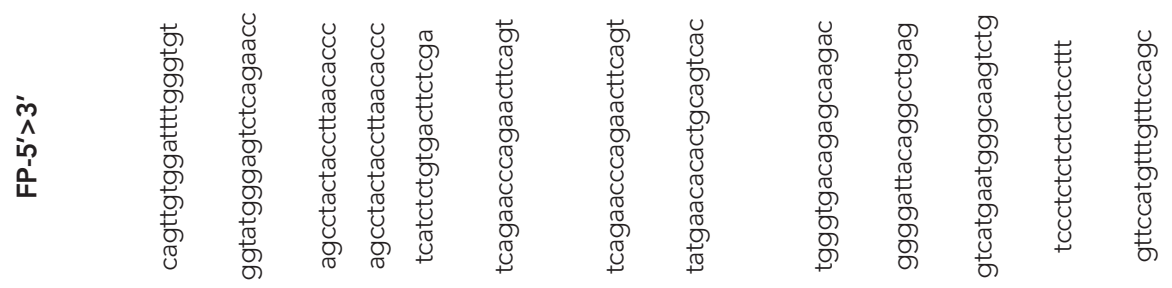

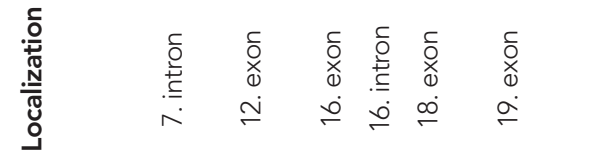

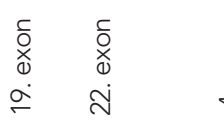

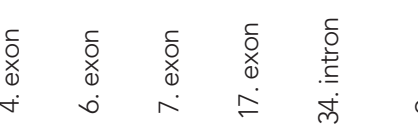

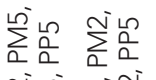

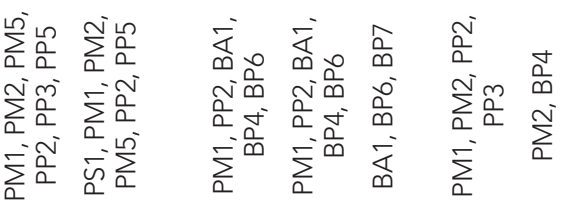

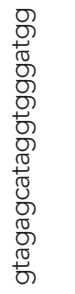

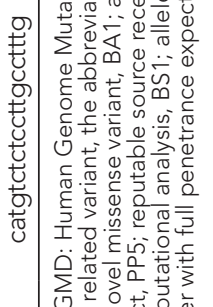

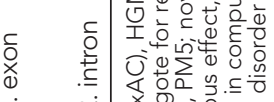

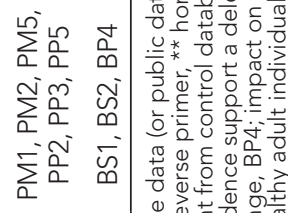

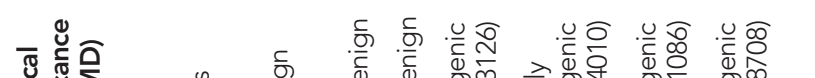

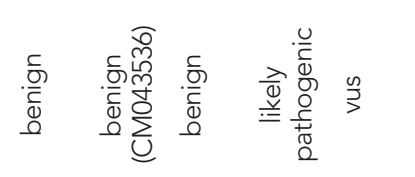

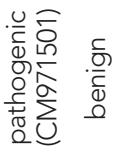

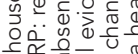
은

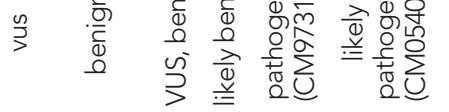

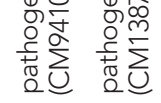
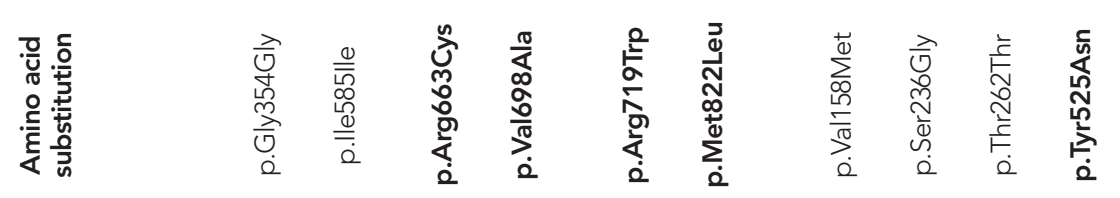

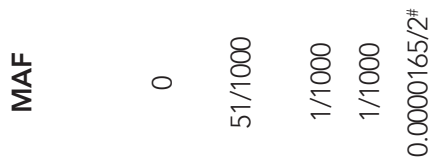

量辛

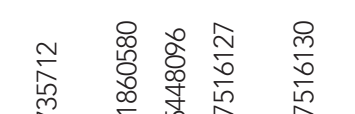

量

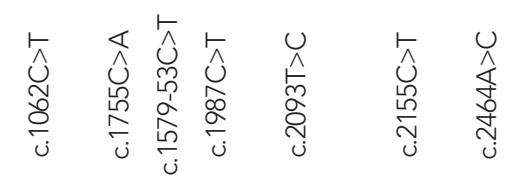

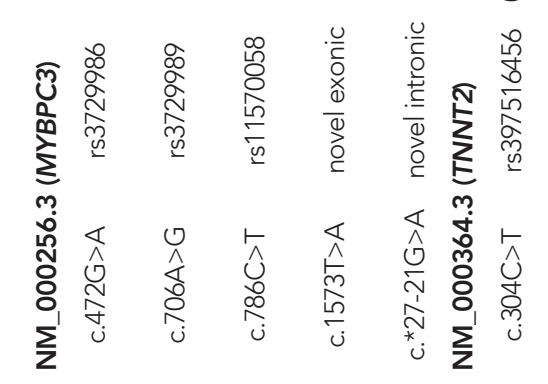

产

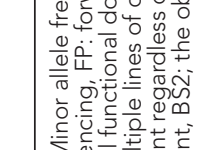

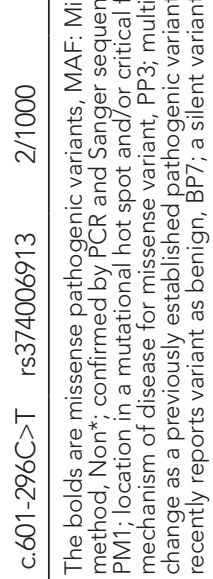


$\overline{\widetilde{\pi}}=$

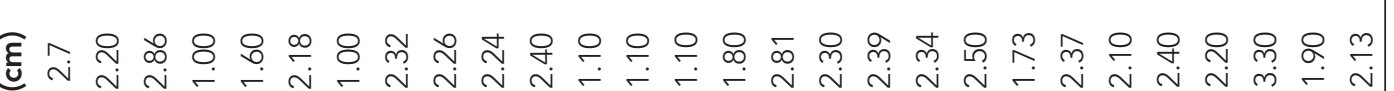

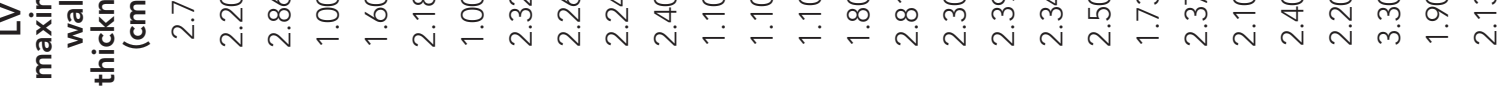
$\frac{1}{t} . \underline{\underline{c}}$

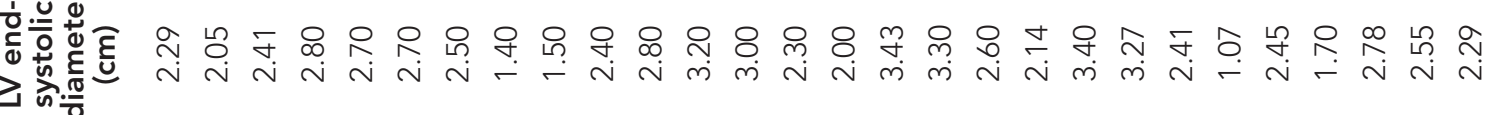
$\frac{1}{t} \div \underline{\underline{0}}$

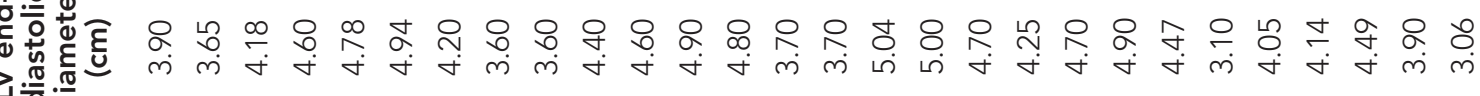

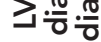

(

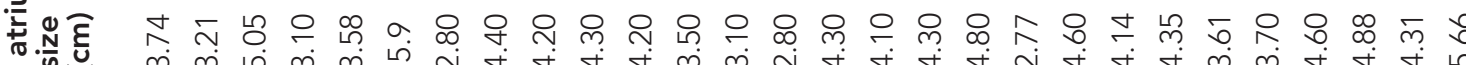
索

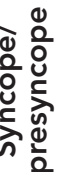

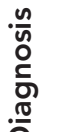

离

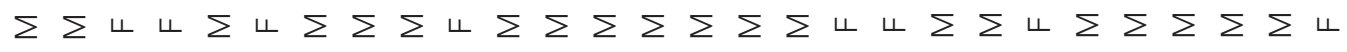

$+\frac{5}{4}$

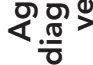

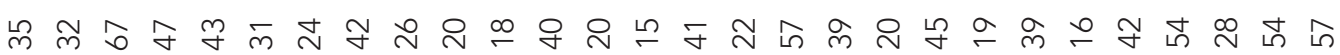

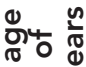

范

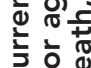

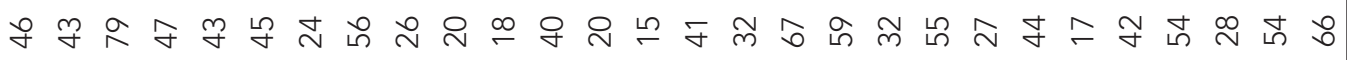

उुㅇํㅇ

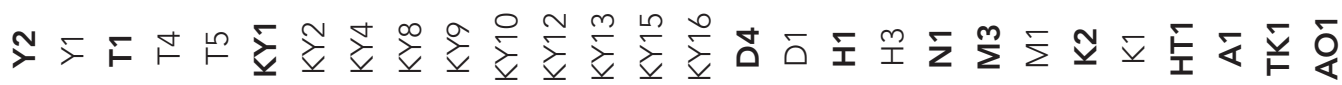




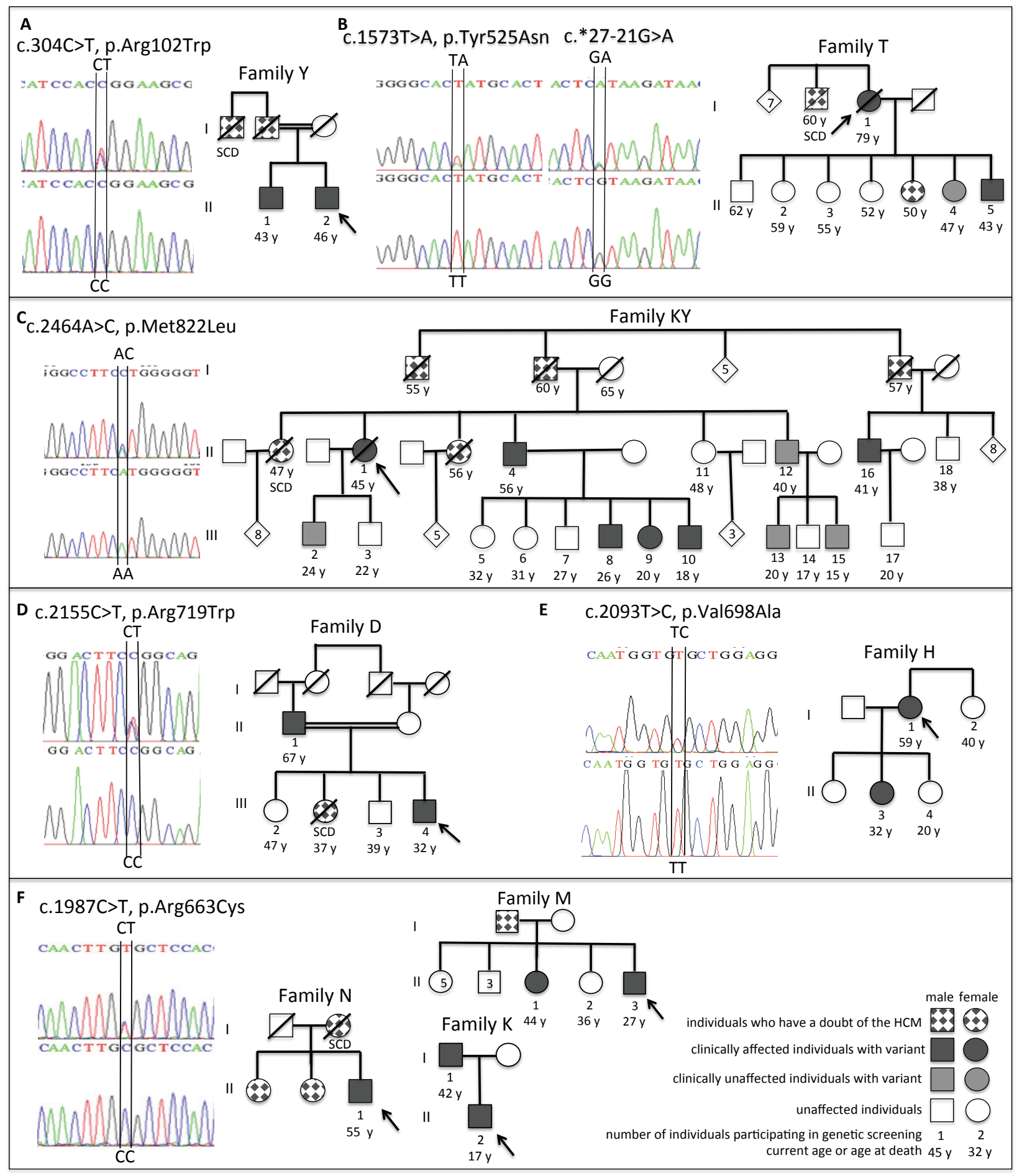

Figure 1: The family screening of the identified clinical significance variants in the TNNT2 (A), MYBPC3 (B) and MYH7 (C-F) genes. Index cases are indicated with arrows.

base and also in public databases (ExAC) (Table 1). The pathogenic variants causing amino acid substitutions and two novel intronic variants (c.639+32G $>\mathrm{T}$ in MYH7 and c. ${ }^{*} 27-21 \mathrm{G}>\mathrm{A}$ in MYBPC3) had not been previously identified in this Turkish in-house database. The main clinical data of the 12 index cases and other clinically diagnosed family members with HCM is summarised in Table 2. 


\section{The pathogenic variants of TNNT2 and MYBPC 3 genes} The previously described Arg102Trp missense variant (also called Arg92Trp) in the TNNT2 gene was found in two brothers with $\mathrm{HCM}$ and a positive family history for SCD in Family $Y$ with consanguineous marriage (Figure $1 A)$. The uncle of the index case had SCD at a young age without clinical diagnosis.

Two novel p. Tyr525Asn and c. ${ }^{*} 27-21 \mathrm{G}>\mathrm{A}$ compound heterozygous variants in the MYBPC 3 gene were identified in another Turkish family with $\mathrm{HCM}$ and a positive family history for SCD (Figure 1B). The c.*27-21G >A variant in MYBPC3 was segregated with a novel Tyr525Asn missense variant in Family T. A genetic analysis could not be performed in a member of Family T with SCD at 60 years old. Index case (T1), with compound heterozygous variants, had mild clinical HCM and possible late onset hypertrophy. Cases T4 and T5 had these compound variants but only T5 had HCM, and T4 with a normal echocardiography (Table 2). Cases T2 and T3 had no variant with normal echocardiographic findings (Figure 1B).

\section{The pathogenic variants of $\mathrm{MYH7}$ gene}

The other four variants causing amino acid substitutions in the MYH7 gene were previously reported missense pathogenic variants in patients with $\mathrm{HCM}$ according to variant databases. The Met822Leu variant in exon 22 of the MYH7 gene was screened in 18 members of Family KY with a positive family history for SCD (Figure 1C). Ten family members were found to have this variant, out of which 6 had severe cardiac hypertrophy. Other 4 asymptomatic pathogenic variant carriers (called as KY2, KY12, KY13 and KY15) had normal echocardiographic findings. The unaffected family members without this variant had no cardiac disease. However, asymptomatic case KY12 and his two sons (called KY13 and KY15) had this variant. The Met822Leu variant site was conserved among the genomes of 35 mammals (GERP score; 4.6), and was determined as disease causing in silico tools (MutationTaster, FATHMM and SIFT).

The Arg719Trp variant in the MYH7 gene was determined in an index case with cardiac defibrillator (implanted for documented ventricular tachycardia) in Family D (Figure 1D). Although, this pathogenic variant seems to be associated with a positive family history for SCD (sister with SCD at age 37 without documentation of HCM), the father (HCM documented) of the index case had a good prognosis without cardiac events.

The Val698Ala pathogenic variant was found to be related with severe cardiac hypertrophy in Family $\mathrm{H}$ (Figure 1E). However, there was no SCD history in this family.

The Arg663Cys pathogenic variant was identified in index cases of three unrelated families (Figure 1F). These three index cases (N1, K2 and M3) also have addition- al individual variants (Table 1). The HCM diagnosis age of this variant carriers $(n=4)$ was less than 42 years old in Family $\mathrm{K}$ and Family M. This variant was also found in the index case (N1) of Family N (mother with SCD without $\mathrm{HCM}$ diagnosis). The cases of two other families (Family $\mathrm{M}$ and Family K) without a history of SCD had mild clinical forms of $\mathrm{HCM}$. The clinical characteristics of the cases diagnosed HCM that were called N1, M1, M3, K1 and K2 in these families are shown in Table 2.

\section{In silico analysis of novel intronic variants}

Two novel clinically uncertain significance variants in the intron 7 of $M Y H 7$ (c.639+32G $>$ T) and in the intron 34 of MYBPC3 (c. ${ }^{*} 27-21 \mathrm{G}>\mathrm{A}$ ) were identified in two HCM patients with a family history for SCD (TK1 and T1 called index cases, respectively). The conservation score among the genomes of 35 mammals were calculated as 3.51 for c. $639+32 \mathrm{G}>\mathrm{T}$ and 4.75 for c. ${ }^{*} 27-21 \mathrm{G}>\mathrm{A}$ in the GERP in silico tool. It was observed that these variants were preserved evolutionarily. The splicing effect of these variants was investigated with in silico analysis using the Alamut software, which integrates several prediction tools (SpliceSiteFinder-like, NNSPLICE, GeneSplicer, Human Splicing Finder, MaxEntScan) and also SR proteins binding site prediction tools (ESEfinder and RESQUE-ESE). In exogenous splice enhancers (ESEs) site tools, these intronic variants have been found to alter motif scores for binding sites of SR proteins (Figure 2A and 2B). The splice site tools of Alamut predicted that the donor splice site scores of c. ${ }^{\star 27}-21 \mathrm{G}>\mathrm{A}$ variant had disappeared (Figure 2C). However, there was no difference in the splice site scores in the c.639+32G $>$ T variant (data not shown). The association of the c.639+32G $>\mathrm{T}$ variant with $\mathrm{HCM}$ could not be determined precisely in TK1 because other family members were not available.

\section{The polymorphic variants of TNNT2, MYBPC3 and MYH7 genes}

The clinically benign variants with the exception of pathogenic exonic and two novel intronic variants were detected in index cases. The information of the gene localization, the effects on codon and allele frequencies of these SNVs are given in Table 1.

This polymorphic variants in index cases were defined according to ACMG (14) (Table 1).

The Ser236Gly missense variant in the MYBPC3 gene, previously associated with $\mathrm{HCM}$ and also available in the Human Genome Mutation Database (HGMD) was identified in three index cases called M3, Y1 and N1.

\section{DISCUSSION}

In this study, disease-causing variants in three HCM-associated sarcomeric genes (MYH7, MYBPC3 and TNNT2) were identified in $67 \%$ of the Turkish families with HCM 


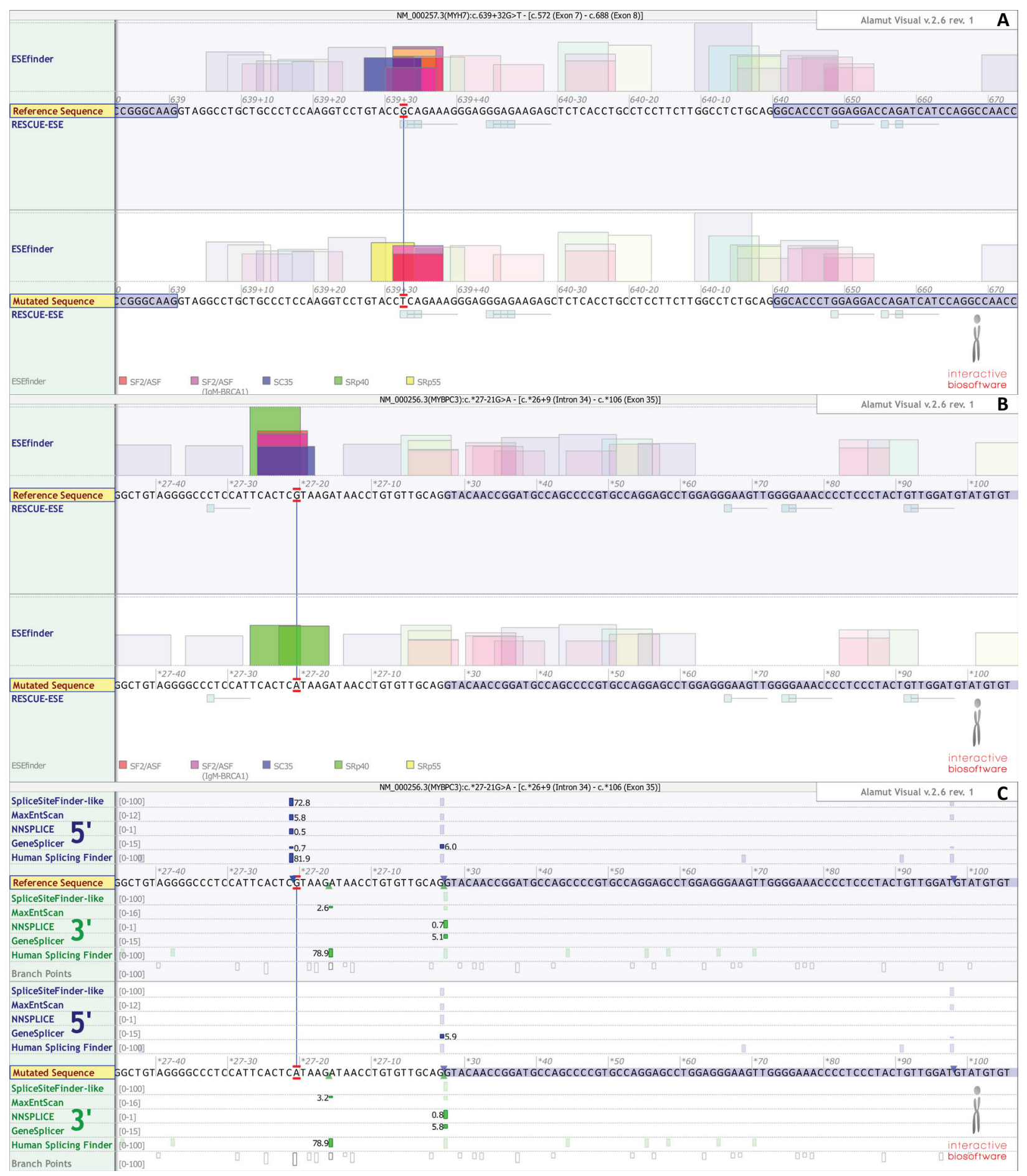

Figure 2: $M Y H 7$ c.639+32G $>$ T and MYBPC3 c. ${ }^{\star} 27-21 \mathrm{G}>\mathrm{A}$ variants with potential effect on the exonic splicing enhancers (ESE) binding site (A and B) and the splicing site (C) as predicted using the Alamut software. The exonic sequences are shown as blue boxes. The splicing site scores from each mutation prediction tool are displayed in blue vertical bars for the $5^{\prime}$ (donor) sites, and as green vertical bars for the $3^{\prime}$ (acceptor) sites.

using sequence-based re-sequencing. The association between these pathogenic variants and SCD risk in familial HCM was also investigated with a retrospective clinical analysis. To date, there is no population-based study to demonstrate the prevalence of hypertrophic cardiomyopathy $(\mathrm{HCM})$ and no large-scale mutation screening 
studies for HCM in Turkey. In previous studies, reported mutations of the MYH7 gene have been demonstrated in Turkish HCM patients $(13,14)$. In the study performed by Kucukates et al., the Arg403G In missense mutation in MYH7 was observed in 8 of 32 cases in 3 families (13). In another study, previously reported four mutations in MYH7 were not found in $18 \mathrm{HCM}$ patients (14). A novel insertion mutation in MYBPC 3 was detected in a Turkish family with $\mathrm{HCM}$ in the mutation screening of the MYB$P C 3$ and MYH7 genes using PCR and Sanger sequencing (15). In addition to pathogenic variants, the identification of functional variants may be important for the modifier or founder effect (16) of variants in the disease phenotype. Therefore, in this study, all individual variants of the index cases were presented, but the population-specific effects of these variants in larger Turkish case-control studies could not be investigated.

The autosomal dominant inherited HCM is a complex disease that is characterized by an heterogenous clinical and genetic expression. It is caused primarily by missense mutations, although causative nonsense, frame-shift, and in-frame insertion/deletion mutations have also been observed, particularly in sarcomeric genes $(3,17)$. As a matter of fact, we have identified missense pathogenic variants in this study. According to the HGMD public database and Pubmed screening with a specific keyword, the Met822Leu missense variant in the MYH7 gene has not been reported previously. However, we found one publication (18) that identified this pathogenic variant with the Alamut software and VarSome, and also another publication (19) that claims to identify the same variant for the first time in the HGMD Professional database. Since the clinical details of variant carriers were not mentioned in these studies, we could not compare them with the findings of our patients. Therefore, further experimental studies should be conducted to demonstrate the clinical significance and the association of this variant with SCD.

In our study, two novel SNVs in the intron 7 of MYH7 (c.639+32G>T) and in the intron 34 of MYBPC3 (c. ${ }^{*} 27$ $21 \mathrm{G}>A$ ) were determined. These variants were analysed to determine possible-binding sites of ESEs for splicesite recognition and for serine/arginine proteins (20) using the Alamut software. In silico analysis predicted that c. ${ }^{*} 27-21 \mathrm{G}>\mathrm{A}$ variant has a possible impact on mRNA splicing but no effect for the c.639+32G $>$ T variant. These results indicate that in vitro studies are required to study the possible impacts of intronic variants on mRNA splicing and expression. However, in this study, the possible effects of these novel defined variants could not be supported by in vitro functional studies.

Furthermore, we identified one novel missense variant, in exon 17 of the MYBPC3 gene (Tyr525Asn). So far, the different mutations related with HCM were reported in the same codon as the Tyr525His (21), the Tyr525Ser (22) and the Tyr525Term (23). The cases with a mild HCM form carrying both Tyr525Asn and c.*27-21G >A variants as compound heterozygote had late-observed SCD in Family T. This intronic variant in the $3^{\prime}-$ UTR of the MYBPC3 transcript suggests that it may affect the mutant allele expression.

In a previous study, similar to our results with family $D$, it was determined that the MYH7 Arg719Trp mutation in four families increased the risk of death associated with $\mathrm{HCM}$ and caused the malignant phenotype (24). The Va1698Ala mutation was firstly identified in Australian proband with hypertrophic cardiomyopathy but there is no clinical information for comparison to our patients (25). The Arg663Cys mutation was described as a "hot spot", and identified nine of the $58 \mathrm{HCM}$ patients (26). This present finding was similar to our results. Indeed, in this study, we found this pathogenic variant in three of the 12 index patients who were not related to each other. In addition, we determined that these three cases had other individual variants besides the main pathogenic variant, and the risk of SCD and cardiac symptoms seems to be different among these three families. These additional polymorphic individual variants might be causing different functional effects on cardiomyocytes with a pathogenic sarcomeric protein.

In our study, the pathogenic variants were not detected in 4 of 12 patients with familial HCM, possibly because disease-causing variants can be found in other HCM-associated genes. In NGS studies applied in recent years, it has been determined that pathogenic variants in both the exonic and intronic regions of more than 40 candidate genes were found to cause the HCM phenotype ( 3 , 8-10). The use of next generation sequencing for the diagnosis of multigenic diseases such as HCM appears to be advantageous to identify all variants. However, as the number of sequenced genes increases, variant analysis becomes difficult, so firstly, candidate genes with a high mutation detection rate can be searched. It is known that $53-85 \%$ of HCM is caused by pathogenic variants in the MYH7, MYBPC 3 and TNNT2 genes $(2,3,11)$. The molecular diagnosis rate of this study was $66 \%$, as in the expected range. As supported by this study's results, a positive family history affects the genetic diagnosis rate of HCM.

In recent studies, as in this study, it has not been confirmed that there is a clear prognostic association between the pathogenic variants and the risk of SCD in $\operatorname{HCM}(3,17)$. Prospective clinical follow-up of these patients with variants will clarify the prognostic importance of these findings. Future advances in genotype-based risk stratification are expected to shed light on the management of these patients, particularly in terms of sudden cardiac death (3). 
Genetic testing in HCM patients is mainly used for the identification of family members at risk of the disease and for genetic counselling (27). Although the mutation-screening strategy in families with HCM is cost-effective (28), the issue still needs to be further evaluated for reproduction, competitive sports and professional career counselling. As a result, despite the fact that most HCM patients have mild clinical symptoms, some patients may suffer from SCD and end-stage heart failure. Therefore, it is important to define the individual variants for a strong genotype-phenotype correlation of HCM observed incomplete penetrance and variable expressivity. On the other hand, experimental studies using approaches such as gene-editing and allele-specific RNA silencing on $\mathrm{HCM}$ treatment in recent years are promising $(29,30)$.

In conclusion, novel variants related with familial HCM and SCD history were identified but the association of these pathogenic variants and SCD was not clear. Variants rather helped other family members to get a clinical diagnosis. Determination of all individual variants in HCM-related genes may be important to demonstrate the inter variant effects on the clinical and structural differences of $\mathrm{HCM}$ families with the same pathogenic variant.

Acknowledgments: We would like to thank TUBITAK-IGBAM for in-house database screening.

Ethics Committee Approval: This study was approved by the Ethical Committee of the Istanbul University School of Medicine (11.02.2011/315).

Informed Consent: Written consent was obtained from the participants.

Peer Review: Externally peer-reviewed.

Author Contributions: Conception/Design of Study- E.K.B., F.B.; Data Acquisition- F.G.G., G.K.; Data Analysis/Interpretation- E.K.B., F.B.; Drafting Manuscript- E.K.B.; Critical Revision of Manuscript- F.B.; Final Approval and Accountability- E.K.B., F.G.G., G.K., F.B.

Conflict of Interest: Authors declared no conflict of interest.

Financial Disclosure: This study was supported by Turkish Society of Cardiology (Project No: 2013/2) and the Scientific Research Projects Coordination Unit of Istanbul University (Project numbers: 42173 and 53021).

Teşekkür: Kurum için veri tabanı taraması için TUBITAK-iGBAM'a teşekkür ederiz.

Etik Komite Onayı: Bu çalışma için etik komite onayı İstanbul Üniversitesi Tıp Fakültesi Etik Kurulu'ndan alınmıştır (11.02.2011/315).

Bilgilendirilmiş Onam: Katılımcılardan bilgilendirilmiş onam alınmıştır.
Hakem Değerlendirmesi: Dış bağımsız.

Yazar Katkıları: Çalışma Konsepti/Tasarım- E.K.B., F.B.; Veri Toplama- F.G.G., G.K.; Veri Analizi/Yorumlama- E.K.B., F.B.; Yazı Taslağı- E.K.B.; İçeriğin Eleştirel İncelemesi- F.B.; Son Onay ve Sorumluluk- E.K.B., F.G.G., G.K., F.B.

Çıkar Çatışması: Yazarlar çıkar çatışması beyan etmemişlerdir.

Finansal Destek: Bu çalışma Türk Kardiyoloji Derneği (Proje No: 2013/2) ve İstanbul Üniversitesi Bilimsel Araştırma Projeleri Koordinasyon Birimi (Proje No: 42173 ve 53021) tarafından desteklenmiştir.

\section{REFERENCES}

1. Maron BJ, Gardin JM, Flack JM, Gidding SS, Kurosaki TT, Bild DE. Prevalence of hypertrophic cardiomyopathy in a general population of young adults. Echocardiographic analysis of 4111 subjects in the CARDIA Study. Coronary Artery Risk Development in (Young) Adults. Circulation 1995;92:785-9. [CrossRef]

2. Maron BJ, Maron MS, Semsarian C. Genetics of hypertrophic cardiomyopathy after 20 years: clinical perspectives. J Am Coll Cardiol. 2012;60(8):705-15. [CrossRef]

3. Jordà P, García-Álvarez A. Hypertrophic cardiomyopathy: Sudden cardiac death risk stratification in adults. Glob Cardiol Sci Pract. 2018;2018(3):25. [CrossRef]

4. Jarcho JA, McKenna W, Pare JA, Solomon SD, Holcombe RF, Dickie S, et al. Mapping a gene for familial hypertrophic cardiomyopathy to chromosome 14q1. N Engl J Med 1989;321:1372-8. [CrossRef]

5. Rodríguez JE, McCudden CR, Willis MS. Familial hypertrophic cardiomyopathy: basic concepts and future molecular diagnostics. Clin Biochem 2009;42(9):755-65. [CrossRef]

6. Meder B, Haas J, Keller A, Heid C, Just S, Borries A, et al. Targeted next-generation sequencing for the molecular genetic diagnostics of cardiomyopathies. Circ Cardiovasc Genet. 2011;4(2):110-22. [CrossRef]

7. Millat G, Chanavat V, Rousson R. Evaluation of a new NGS method based on a custom AmpliSeq library and Ion Torrent PGM sequencing for the fast detection of genetic variations in cardiomyopathies. Clin Chim Acta 2014;433:266-71. [CrossRef]

8. Waldmüller S, Schroeder C, Sturm M, Scheffold T, Imbrich K, Junker $S$, et al. Targeted 46-gene and clinical exome sequencing for mutations causing cardiomyopathies. Mol Cell Probes 2015; 29:308-14. [CrossRef]

9. Mendes de Almeida R, Tavares J, Martins S, Carvalho T, Enguita FJ, Brito D, et al. Whole gene sequencing identifies deep-intronic variants with potential functional impact in patients with hypertrophic cardiomyopathy. PLoS One 2017;12(8):e0182946. [CrossRef]

10. Bottillo I, D'Angelantonio D, Caputo V, Paiardini A, Lipari M, De Bernardo C, et al. Molecular analysis of sarcomeric and non-sarcomeric genes in patients with hypertrophic cardiomyopathy. Gene 2016;577:227-35. [CrossRef]

11. Ho CY, Charron P, Richard P, Girolami F, Van SpaendonckZwarts KY, Pinto Y. Genetic advances in sarcomeric cardiomyopathies: state of the art. Cardiovasc Res 2015;105:397-408. [CrossRef] 
12. Richards S, Aziz N, Bale S, Bick D, Das S, Gastier-Foster J, et al; ACMG Laboratory Quality Assurance Committee. Standards and guidelines for the interpretation of sequence variants: a joint consensus recommendation of the American College of Medical Genetics and Genomics and the Association for Molecular Pathology. Genet Med. 2015;17(5):405-24. [CrossRef]

13. Kucukkates E, Ersanli M, Gultekin N, Sayhan N, Mutlu $H$, Kalfoglu $E$, et al. Clinical Investigations 403Arg-Gln Missence Point Mutation of B-Myosin-Heavy-Chain in Hypertrophic Cardiomyopathy Families in a Diverse Turkish Population and its Relation with Sudden Cardiac Death. Turk Kardiyol Dern Ars 1999;27:664-71.

14. Cam FS, Terzioglu O, Sagan A, Nalbantgil I, Ozerkan F, Ozdamar M, et al. Detection of Arg403GIn, Arg453Cys, Arg719Trp and Arg719GIn Mutations in the B-Myosin Heavy Chain Gene (B-Mhc) Causing to Hypertrophic Cardiomyopathy. Turk Kardiyol Dern Ars 2002;30:30-5.

15. Hallioglu Kilinc O, Giray D, Bisgin A, Tug Bozdogan S, Karpuz D. Familial hypertrophic cardiomyopathy: A case with a new mutation in the MYBPC3 gene. Turk Kardiyol Dern Ars 2017:45:450-3. [CrossRef]

16. Christiaans I, Nannenberg EA, Dooijes D, Jongbloed RJ, Michels M, Postema PG, et al. Founder mutations in hypertrophic cardiomyopathy patients in the Netherlands. Neth Heart J 2010;18(5):248-54. [CrossRef]

17. Landstrom AP, Ackerman MJ. Mutation type is not clinically useful in predicting prognosis in hypertrophic cardiomyopathy. Circulation 2010;122(23):2441-9; discussion 2450. [CrossRef]

18. Mohiddin SA, Begley DA, McLam E, Cardoso JP, Winkler JB, Sellers JR, Fananapazir L. Utility of genetic screening in hypertrophic cardiomyopathy: prevalence and significance of novel and double (homozygous and heterozygous) betamyosin mutations. Genet Test 2003;7(1):21-7. [CrossRef]

19. Fujino N, Konno T, Hayashi K, Hodatsu A, Fujita T, Tsuda $T$, et al. Impact of systolic dysfunction in genotyped hypertrophic cardiomyopathy. Clin Cardiol 2013;36(3):1605. [CrossRef]

20. Wang J, Smith PJ, Krainer AR, Zhang MQ. Distribution of SR protein exonic splicing enhancer motifs in human proteincoding genes. Nucleic Acids Res 2005;33(16):5053-62. [CrossRef]
21. Lopes LR, Zekavati A, Syrris P, Hubank M, Giambartolomei C, Dalageorgou C, et al. Genetic complexity in hypertrophic cardiomyopathy revealed by high-throughput sequencing. J Med Genet 2013;50(4):228-39. [CrossRef]

22. Girolami F, Olivotto I, Passerini I, Zachara E, Nistri S, Re F, et al. A molecular screening strategy based on beta-myosin heavy chain, cardiac myosin binding protein $\mathrm{C}$ and troponin T genes in Italian patients with hypertrophic cardiomyopathy. J Cardiovasc Med (Hagerstown) 2006;7(8):601-7. [CrossRef]

23. Bortot B, Athanasakis E, Brun F, Rizzotti D, Mestroni L, Sinagra G, Severini GM. High-throughput genotyping robot-assisted method for mutation detection in patients with hypertrophic cardiomyopathy. Diagn Mol Pathol 2011;20(3):175-9. [CrossRef]

24. Anan R, Greve G, Thierfelder L, Watkins H, McKenna WJ, Solomon S, Vecchio C, Shono H, et al. Prognostic implications of novel beta cardiac myosin heavy chain gene mutations that cause familial hypertrophic cardiomyopathy. J Clin Invest 1994;93(1):280-5. [CrossRef]

25. Ingles J, Doolan A, Chiu C, Seidman J, Seidman C, Semsarian C. Compound and double mutations in patients with hypertrophic cardiomyopathy: implications for genetic testing and counselling. J Med Genet 2005;42(10):e59. [CrossRef]

26. Van Driest $\mathrm{SL}$, Jaeger MA, Ommen SR, Will ML, Gersh BJ, Tajik AJ, Ackerman MJ. Comprehensive analysis of the beta-myosin heavy chain gene in 389 unrelated patients with hypertrophic cardiomyopathy. J Am Coll Cardiol 2004;44(3):602-10. [CrossRef]

27. Restrepo-Cordoba AM, Campuzano O, Ripoll-Vera T, CoboMarcos M, Mademont-Soler I, Gámez JM, et al. Usefulness of Genetic Testing in Hypertrophic Cardiomyopathy: an Analysis Using Real-World Data. J Cardiovasc Transl Res 2017;10(1):35-46. [CrossRef]

28. Ingles J, McGaughran J, Scuffham PA, Atherton J, Semsarian C. A cost-effectiveness model of genetic testing for the evaluation of families with hypertrophic cardiomyopathy. Heart 2012;98(8):625-30. [CrossRef]

29. Jiang J, Wakimoto H, Seidman JG, Seidman CE. Allelespecific silencing of mutant Myh6 transcripts in mice suppresses hypertrophic cardiomyopathy. Science 2013;342(6154):111-4. [CrossRef]

30. Ma H, Marti-Gutierrez N, Park SW, Wu J, Lee Y, Suzuki K, et al. Correction of a pathogenic gene mutation in human embryos. Nature 2017;548(7668):413-9. [CrossRef] 